Pour le Piétrain à la carcasse très riche en viande cette dernière garde une teneur en lipide qui garantit sa tendreté II,I9/77,90. Ainsi observe-t-on qu'une carcasse maigre peut très bien donner une viande suffisamment chargée en lipide pour rester tendre.

En outre on a observé que la teneur en lipide dépendait de l'alimentation : les lots qui ont reçu l'aliment le plus riche en maïs présentaient un pourcentage plus élevé de graisse de constitution.

Ainsi, grâce à la génétique et en surveillant l'alimentation, on peut obtenir un porc dont les qualités de viande surpassent nettement celles des races pures traditionnelles.

\title{
EFFECTIVENESS OF BOAR PERFORMANCE TEST SELECTION INDEXES
}

E. P. Cunningham and P. Power. - Animal Breeding and Genetics Department, An Foras Taluntais, Dublin. - Livestock Section, Dept. of Agriculture and Fisheries, Dublin (Eire).

Five possible indexes for use in selecting boars on performance test were evaluated. The selection objective in all cases was a linear economic function of the boars's genotype for daily gain, feed efficiency and carcass lean content. Eleven items of information were available for inclusion in the index. These were the recorded daily gain, feed efficiency and backfat of boar, two full sibs and nine half sibs, together with part carcass dissection data on two full and six half sibs. The indexes considered were :

r. Full index including $\mathbf{r}$ items of information.

2. Information on feed efficiency omitted.

3. Information on feed efficiency and part carcass dissection omitted.

4. All half and full-sib information omitted.

5. All half-sib information omitted.

The relatives rates of genetic change to be expetecd from using these indexes were roo, 9o, 85, 86 and 96. Within each index, boar backfat was the most useful item of information, followed by boar feed efficiency, or, where feed efficiency was not recorded, boar daily gain.

The most valuable item of sib data was the part dissection on two full sibs, though its omission never caused more than a $4 \mathrm{p}$. Ioo drop in index efficiency.

The percentage of the economic value of the genetic gain achieved attributable to change in each trait was measured. The proportions were quite similar for all indexes. About 6 p. Ioo was due to improvement in daily gain, 33 p. Ioo to improvement in feed efficiency and 6r p. Ioo to increased carcass lean content. 